\title{
Recording and analysis of ship graffiti in St Thomas' church and Blackfriars Barn undercroft in Winchelsea, East Sussex, UK
}

\author{
Thomas Dhoop, Catriona Cooper, Penny Copeland \\ Centre for Maritime Archaeology, Department of Archaeology, University of Southampton, Highfield, \\ Southampton SO 17 1BF, UK
}

\section{Summary}

Two assemblages of ship graffiti were recorded using Reflectance Transformation Imaging (RTI) in the ancient port town of Winchelsea. The engravings show characteristics common to most medieval ship graffiti in England, while displaying a certain variety in the level of detail and quality in which ships can be represented using this medium, encouraging a nuanced understanding. It is suggested that, despite these complexities, the ship graffiti demonstrate a multifaceted relationship with the sea. The St Thomas' church graffiti could have been a means of spiritual protection and a devotional practice that cuts across different communities of practice and social groups, while the seascape in Blackfriars Barn undercroft can be interpreted as an occasion of informal remembrance of the mustering of a large naval fleet before setting out.

Key words: Ship depictions, graffiti, churches, undercrofts, reflectance transformation imaging

\section{Introduction}

In the spring of 2015, the University of Southampton conducted the first phase of the Winchelsea Harbour Geotechnical Survey 2015 project, aimed at establishing an integrated dataset of geophysical, geological and pictorial information on the medieval port town of New Winchelsea (Dhoop 2015a). As part of this project, the ship graffiti located in the parish church of St Thomas the Martyr and the undercroft underneath the Blackfriars Barn building - a property of the National Trust - were recorded using Reflectance Transformation Imaging (RTI) (Figure 1).

This article provides a thorough description and analysis of the recorded graffiti and interprets them on several contextual scale levels. First as artefacts and depictions of ships as things-in-themselves, second as part of the buildings in which they were made, and third as part of the communities' shared ritual behaviour. It is argued that the variety in the level of detail and quality of the recorded ships some could even be understood as something different from a ship all together - lays bare some of the complexities involved in interpreting, dating and finding meaning in ship graffiti and encourages a nuanced and complex understanding of this phenomenon in the past. Nonetheless, this article will tentatively argue that both assemblages can be attributed to the close connections between the townspeople of Winchelsea and the sea. This relationship was multifaceted and resulted in people carving ships in St Thomas' church to acquire some form of spiritual protection from the sea, while (at the same or a different time) carving them in the (ostensibly) secular Blackfriars Barn undercroft to commemorate the benefits of this relationship. 


\section{Interpreting ship graffiti}

Medieval ship graffiti can be found in buildings all over England and often, but not exclusively, occur in an ecclesiastic context (Emden 1922; Pritchard 1967: 88-9, 123-5, 131-3, 140, 1987; Miller 2003; Gardiner 2007; Champion 2015a: 83-97, 2015b), although they are not limited to standing structures and are sometimes found on artefacts as well (Liebgott 1973, le Bon 2001). The majority have been found in churches, leading to interpretations that they were religious in nature (Champion 2012b: 111, 2015a: 91-93, 2015b: 344-9, Peake 2012: 160-1, Westerdahl 2013: 344). Friel (2011: 85) however, is of the opinion that this has more to do with the fact that medieval churches have generally survived better than medieval secular buildings. Recent surveys, such as The Norfolk Medieval Graffiti Survey (Champion 2011), appear to confirm this, as ship graffiti are now increasingly being recorded in secular contexts as well. Examples come from Acton Court in Bristol (Friel 2004), Tudor House in Southampton (Perry 2010) and seemingly the Blackfriars Barn undercroft (Champion 2012a) discussed in this paper. The majority of ship graffiti can be found at coastal sites, suggesting a link with maritime communities. However, recently examples are being found in landlocked places as well (Champion 2015a: 86, 2015b: 350). It appears that writing and drawing on buildings of all kinds was a common and accepted thing to do (Fleming 2001: 36, 38, Friel 2011: 85, Peake 2012: 160).

Ship graffiti have often been given special consideration as visual evidence. Representing a form of 'folk art', to use Friel's words (2011: 92), free of artistic convention, they have been considered the work of people who drew what they knew or what they could see. Westerdahl (2013: 337) has pointed out that this initially led to a rather one-dimensional functionalist approach focussed on learning about the technology of ships in the past (Bonino 1975: 291, Emden 1922: 171, Mott 1990). While Westerdahl certainly is correct that a disproportionate amount of attention has gone to the description of the ships themselves (Pritchard 1967: 123-5, 131-3, 140), rather than contextualisation and meaningful interpretation, the authors of this paper nonetheless believe that there is a place for the analysis of techno-functional aspects. Peake (2012: 160) points out that studies of graffiti often come down to three questions: when, why and by whom were they created? As this paper develops answers to these queries, the study of technical features is part of the analytical process and the results contribute to some of the arguments presented.

Recently, a more nuanced understanding of ship graffiti has been adopted. It is now widely acknowledged that some ship graffiti show technical features that most likely only people with knowledge of nautical affairs would have understood, while other examples might be no more than a simple visual 'shorthand' for portraying a ship (Friel 2011: 92), in other words, carvings that could have been made by 'anyone and everyone' (Champion 2015a: 89). In light of a growing corpus of graffiti representing ships in a similar way, also the idea that no conventions are involved is being questioned and a list of features 'typical' to medieval (pre-reformation) English ship graffiti has been suggested by Champion (2015b: 344). Although already noted in passing by Pritchard in the late 1960s (1967: 131), over the past five years, the interpretation of these engravings has shifted towards an emphasis on their significance as parts of religious ritual or popular magic and it is now generally argued that at least some of the examples found in churches should be understood as 'the poor man's votive ships' (Peake 2012: 160-1, Champion 2012b: 111, 2015a: 93-96, Westerdahl 2013: 344).

\section{Ship graffiti in Winchelsea}

Winchelsea, refounded in the late 1280s after severe coastal erosion of its original site, was a major planned royal port. Until its relative decline from the middle of the $14^{\text {th }}$ century (however see Jervis 2015), the town was an important member of the Cinque Ports Confederation and one of the principal ports of the English realm (Cooper 1850; Sylvester 1999a, 1999b; Martin \& Martin 2004). 
It is therefore not surprising that Winchelsea houses two significant collections of ship graffiti. Both have, in some shape or form, been looked at before. With the help of archaeologist and graffiti expert Matthew Champion, in June 2012, the Winchelsea Archaeological Society (WAS) initiated the Winchelsea Historic Graffiti Survey Project which aims to discover and record as much as possible of the graffiti in the town. At least some of the carvings of ships in St Thomas' church have since been recorded by a photographic and drawn survey. While they are frequently mentioned in publications by Champion (2012b: 111-5, 2015a: 94-96, 2015b: 347-348), they were never fully published. The latter has noted that the majority of the ship graffiti are located on a single column in the eastern end of the north arcade. Although Cooper (1850: 123) guessed that St Nicholas' chapel was located within the south arcade and the Chapel of Our Lady in the northern one, research by Blair et el. (2000: 19) on the tomb monuments suggests that the locations were the other way round (Martin \& Martin 2004: 80). Champion therefore argues that the graffiti could be devotional in nature and should be seen in the light of a growing corpus of ship depictions associated to this saint (other examples come from Blakeney, Brighton and King's Lynn, see Champion 2015a: 93-95). He interprets the ships as large seagoing vessels and further hypothesises that they might be an aspect of lay piety that reflects the ambiguous relationship the community had with the erratic nature of the sea (Champion 2012b: 1115, Champion 2015a: 96).

The graffiti in the Blackfriars Barn undercroft were only recently rediscovered. In 1976-77, archaeologists removed accumulated debris from the cellar and in 2005 volunteers from WAS, under supervision of Luke Barber of the Sussex Archaeological Society, cleared the undercroft of further loose rubble. During subsequent remedial work, in preparation for opening up the site to the public, a large graffito was observed on the northern wall of the western chamber. It was first recorded in 2010 by Catriona Cooper using an early version of Reflectance Transformation Imaging, but the recordings were never analysed. In 2012, the graffiti was recorded by Champion (2012a) using a series of raking lights and multiple fixed camera position, allowing the creation of full map overlay images of very small sections of the northern wall. In his analysis, Champion writes that the ship images most likely depict sea-going vessels of an early date, which he supports with the presence of topcastle's on some of the vessels, which he states would not have been present on riverine vessels. Based on comparisons with medieval iconographic material, in particular manuscript illuminations (Flatman $2002,2009)$, Champion identifies the ships as 'cogs' or 'early carracks'. Based on this identification, he argues for a tentative terminus post quem of ca. 1550, but most likely between 1350 and 1450 . In a subsequent contribution to the National Trust Arts, Buildings and Collections Bulletin, Champion and Nathalie Cohen (2013: 8) argue that, despite their location in an ostensibly secular building, it is likely that the graffiti in Blackfriars Barn undercroft were made as a ritual and symbolic act, perhaps commemorating the English victory at the 'Battle of Winchelsea' in 1350.

While most of the graffiti had been recorded in some shape or form before, it was deemed relevant to re-record the engravings on both locations for several reasons. Most straightforward is that the graffiti in St Thomas' church had never been comprehensively published. Secondly, it must be acknowledged that any drawing of an artefact is an interpretation, and therefore subjective. Thirdly, given that RTI allows for a very minute recording of the engravings, the RTI-models could be considered as pieces of 'raw data', easily accessed through open-source software, from which different scholars can draw their own conclusions. Finally, none of the graffiti had been examined by a researcher with expertise in ship archaeology.

\section{Method of survey}

The recording was conducted using a computational photographic technique called Hemispheral Harmonics (HSH) (Manfredi et al. 2013), part of a larger family of techniques known as Reflectance 
Transformation Imaging (RTI). Over the past decade, RTI has been shown to be a robust and useful technique for surface imaging of cultural heritage and has been deployed to record a wide spectrum of archaeological and conservation pieces (e.g. Malzbender et al. 2001; Hammer et al. 2002: 9; Earl et al. 2010; Freeth et al. 2006; Gabov \& Bevan 2011; Klausmeyer 2013).

RTI has become widely established in archaeological practice and a good summary of how it works can be found in Earl et al. (2010: 2041-3). RTIs popularity in a heritage recording and conservation setting stems from its ability to extract an approximation of a surface's geometry based on ordinary digital photos. This geometry is pixel-encoded and rendered within open-access viewer software that allows relighting of the object under a variety of reflectance property transformations (Figure 2). The result is formidable surface detail enhancement, proving particularly useful when such details have been worn by the elements as was the case with the plaster surface in the Blackfriars Barn undercroft. Although digital recording systems can raise questions about data quality and authenticity, this topic has been adequately addressed in the specialised literature by comparing RTI images with other imaging methods (Mudge et al. 2008, Miles et al. 2014: 601-4, Miles et al. 2015: 150-2). Good examples of the suitability of RTI for this sort of recording come from Mudge et al's work on the conservation of Roman and ancient Greek coins (2005) and Paleolithic rock art (2006). In the first study they were able to visualise remnant impressions on worn coins, while in the second study it proved possible to trace the temporal sequence of overlapping engraved lines in rock art.

In practice, a DSLR was mounted on a tripod and placed at a fixed position at an appropriate distance from and level with the surface that needed recording. Considering that the recording in St Thomas' church took place on columns with a curved surface, sometimes it was needed to repeat the exercise around the column to pick up any missed details. A red sphere was positioned close to the column or wall and in the picture frame. A remotely operated flash was used as a light source. Covering several diagonals, the flash was moved by hand in an arching movement from the bottom to the top of the graffiti. This means that between 45 and 115 photos were taken under raking light conditions, depending on the size of the graffito that was being recorded. This resulted in a 'starfish' coverage of lighting angles for the RTIBuilder software to work with (Figure 3). Using the HGH's as a basis, each recorded graffito was subsequently traced by hand using the raster graphics editor program GIMP 2 .

\section{Ship graffiti in St Thomas' church}

St Thomas is the current parish church of Winchelsea (Figure 1). Originally conceived on the scale of a small cathedral after the relocation of Winchelsea to its present site around 1288 , today only the eastern end and the ruins of the transept remain (Figure 4). Despite there being some debate whether the building was ever finished - a recent resistivity survey failed to locate the missing foundations (Dhoop 2015a) - most follow David and Barbara Martin's argument that, following a major decline in population in the $16^{\text {th }}$ century, the church was downsized and the redundant part sold for its materials (see Martin \& Martin 2004: 74-80 for a discussion). The inside of the remaining structure has a good collection of graffiti, including a substantial number of ship graffiti.

In total, eleven graffiti were recorded (Figures 5, 6, 7, 8 and 9) that could possibly be identified as ships. All engravings of ships are located on the two northern columns, but the majority can be found on the eastern one (Figure 4). Three graffiti on the western column (St Thomas 9, 10 \& 11) were not recorded during the RTI-survey, having previously been recorded by the author and Sarah Stark in October 2014 using the traditional method of raking light and digital photography. Each graffito was drawn and described individually in a grey literature report that can be requested from the National Trust (Dhoop 2015b). 


\section{Interpretation}

The ship graffiti in St Thomas' church vary in terms of quality and level of detail. St Thomas 1 and 6 show fairly detailed depictions of ships, while St Thomas 4, 5, 8 and 11 are more basic inscriptions. St Thomas 2, 3, 7, 9 and 10, on the other hand, are so rudimentary that they could just as well be interpreted as depicting very different things, such as the base of a house or part of a plough (pers. comm. Matthew Champion 2015). However, given the similarities that they display with the confirmed ship graffiti and their placement on pillars that contain several other ship depictions, these rudimentary inscriptions were also included in the assemblage.

The ship graffiti in St Thomas' church generally depicts vessels with a straight stern while both straight and curved stems occur. The strakes run in straight lines between the latter two elements. About half also depict superstructures both at the bow and stern. Most show a single mast, some with a yard, furled sail and stays and / or shrouds. One graffito, St Thomas 1, clearly has a sternpost rudder (Figure 5). However, the straight stern discernible on most of the ships implies that they most likely represent vessels with sternpost rudders as well. At least three engravings might show ships lying at anchor (Table 1). All of these characteristics are common to most medieval ship graffiti in England (Champion 2015b: 344). However, there are no indications in the engravings that they necessarily represent large seagoing vessels (none have topcastles for example, contrary to the ships in the Blackfriars Barn undercroft).

Less common is the large triangle on top of the yard in St Thomas 5 (Figure 6). If the triangle is part of the ship graffito, it is possible that this shape attempts to show the configuration of two lifts holding up a yard. When observing ships with their sails furled, such triangles are indeed the shape that the yard and lifts will take. If this is the case, then this would imply that these observations were made in the context of a mooring, rather than the open sea.

Also notable is the pair of inscriptions classified here as St Thomas 3 (Figure 7). Winchelsea is known to have built ships (Tinniswood 1949: 277; Hutchinson 1994: 151). In this light, and if the pair were meant to depict ships, they could illustrate a construction sequence. This would suggest that the person who made them had at least a rudimentary understanding of shipbuilding. If the graffiti is to be seen this way, the bottom image could depict the first phase of construction: the laying of the keel and subsequent raising of the stem and stern, while the top image could depict the subsequent stage of attaching the garboard strakes.

Finally, also the anchor lines visible in St Thomas 1 and possibly also 6 (Figures 5 and 8), anchoring the ship at both the bow and the stern are noteworthy. Traditionally, a ship is held in a fixed position by deploying an anchor at the bow. However, in a tidal roadstead, which would have been the dominant method of anchoring in Winchelsea's harbour (Draper 2009: 31), this would mean that ships could drift and swivel as the tide goes in and out, potentially causing anchor lines to tangle. This can be avoided by anchoring the vessel at both the bow and stern, keeping the vessel in place. This could suggest that the person who made these graffiti had some knowledge of anchoring methods, or perhaps had observed them in use.

Is it also possible to identify what sort of ships these engravings aim to depict? If the graffiti do not represent a generic ship, but are based on some form of knowledge of what a ship looked like probably not uncommon in a port town - there are, archaeologically speaking, three ship-shapes to consider; those of the Nordic ship, cog and carvel. The term Nordic is not used in an ethnic sense in this paper, but to designate the boat and shipbuilding tradition that originated in Scandinavia and subsequently spread to most of northern Europe, including England (Crumlin-Pedersen 2004: 43). 
Nordic vessels were shell-built in terms of their construction, and lapstrake-built throughout in the way that principle was applied (Adams 2013: 211). In terms of their overall appearance, seagoing Nordic ships, from at least the $13^{\text {th }}$ century, had a curved stem, straight stern with sternpost rudder and overlapping strakes running relatively straight from stem to stern. The term cog, or more appropriately 'cog of the archaeological definition', is used to refer to the archaeologically-attested shipbuilding tradition (Dhoop forthcoming). Cogs were distinguishable from Nordic seagoing ships by a number of technological features (Crumlin-Pedersen 2000: 232-3), most of which were hidden below the waterline or inside the vessel. Perhaps the most important was that cogs had a bottom made out of planks that lay flush, meaning that they did not overlap, while their sides were clinker-built, running fairly straight from stem to stern, as was the case in Nordic ships. Cogs had a high-raking straight stem, straight stern with sternpost rudder and generally had a 'fuller' shape in the midship area. If the graffiti dates to after the 1440s (Friel 1995: 164; Adams 2013: 70), also ships built in the carvel tradition having their hull planks laid flush onto the framing timbers - could have been carved from observation. In overall appearance, ships built in the carvel tradition might have looked fairly similar to medieval seagoing Nordic vessels, especially when one is attempting to carve them in profile view. Both would have had a curved stem, straight stern with sternpost rudder and strakes running straight from stem to stern, the difference being that in carvel ships, the strakes lie flush.

However, a survey of medieval iconography suggests that also the double-ended variation of Nordic ships (with curved ends), more commonly associated with Viking Age vessels, and ships built in the socalled 'hulc tradition' were part of the medieval visual repertoire (Flatman 2009: 69-95). Although it is unlikely that many seagoing double-ended Nordic vessels would still have visited late $13^{\text {th }}$ century Winchelsea, it is possible that smaller craft used locally, were still built double-ended (see the Oselvar boats in Norway for an example of how ancient boatbuilding traditions live on in smaller craft, Færøyvik 1987). The late medieval hulc tradition is problematic. No examples have been found in the archaeological record and the tradition's existence is attested only by documentary and iconographic data, supported by ethnographic analogies (Greenhill 2000). Adams (2013: 99-110) has recently convincingly argued that the late medieval hulc as a building tradition separate from the Nordic tradition is most likely a myth. Nevertheless, images of hulcs, showing vessels with strakes curving upwards, terminating in horizontal lines at the stem or stern (or both), are common in the work of professional artists (Flatman 2009: 87-91) and those making graffiti (Pritchard 1987: 319, Figure 5, Champion 2012b: 112, Figure 6). Friel however, although not discounting that 'hulc' vessels at some point might have existed, has wondered whether some of the 'hulc' ship graffiti were no more than a visual 'shorthand' for portraying a ship (2011: 93).

Given that all ships depicted in St Thomas' church have strakes that run straight from stem to stern, it is clear that both Nordic vessels of the double-ended type and 'hulc' ships are absent. However, when dealing with crude depictions of vessels in profile view, a carvel and Nordic ship could be visually indistinguishable, while a cog of the archaeological definition might only be distinguished by a highraking straight stem. In essence, it comes down to the question whether the maker of the graffito chose to etch a straight or curved line. When using this (admittedly oversimplified) rule of thumb, it would appear that, depending on their date, the medieval Nordic, cog and carvel traditions could all be represented in the graffiti in St Thomas' church.

\section{Dating}

The only stylistic features which might offer a clue to the date of the graffiti in the St Thomas' church are the single mast and the straight stern implying the use of a sternpost rudder. However, as was noted above, these characteristics are common to most ship graffiti in English buildings. Yet, there are differences between these and ship graffiti from the seventeenth and eighteenth centuries. The latter 
appear not to be associated with any particular area of the church, and more significantly, they tend to show large multi-masted vessels (Champion 2015a: 88). The introduction of a second mast on English ships can possibly be traced back to a single instance of technological adaption. In 1416-17, the English captured six large, two-masted Genoese carracks that had been hired by the French. Immediately after this, between 1416 and 1420, six English ships were fitted with a two-masted rig and by 1420 this second mast was called 'mesan' (Friel 1994: 80; Adams 2013: 70). A sternpost rudder is first shown on boats depicted on the fonts at Winchester in Hampshire and Zedelgem in West Flanders, Belgium. Both have been dated to the second half of the $12^{\text {th }}$ century. Sternpost rudders first appear on Nordic ships on the $13^{\text {th }}$ century seals of Poole and Ipswich (McGrail 2001: 232).

As both single masts and sternpost rudders would have been prevalent by the time the St Thomas' church was built, a dating based on ship architecture is problematic. The earliest possible date that the graffiti could have been made should instead be situated around the time the church was taken into use. Unfortunately, a date for the completion of the St Thomas' church is unknown. However, in 1291, the building was valued at $f 10$ 13s $4 d$ (Martin \& Martin 2004: 74), suggesting it might have been under construction, and providing a very rough terminus post quem.

A latest possible date for the creation of the graffiti is possibly even harder to establish. If the people making these engravings were indeed drawing what they saw, could a terminus ante quem be suggested based on the introduction of a second mast, plus a ca. 30 year period for most of the English fleet's large seagoing vessels to adapt: ca. 1450 ? This is problematic given that single-masted vessels would not have disappeared and would still have been built and observed. Additionally, such a reasoning would entail the assumption that the ships are meant to represent large vessels, for which there is no indication in the graffiti. A more reliable terminus ante quem could be the moment when New Winchelsea fell out of use as a harbour: ca. 1530 (Martin \& Martin 2004: 198). However, as ship graffiti are also found in land-locked environments (Champion 2015a: 86, 2015b: 350), also this date should be considered tentative.

\section{Context and meaning}

Given the spatial configuration of the graffiti - located on the two pillars across from the former St Nicholas chapel - and established interpretations of similar graffiti in English (Peake 2012) and northern European churches (Westerdahl 2013), Champion's (2012b: 111, 2015a: 94-96, 2015b: 347348) explanation of the ships as devotional in nature seems fair. If they are to be interpreted as part of a Christian tradition of giving a votive offering in an act of prayer, hoping to assure - or give thanks for - a safe journey across the sea, then this assemblage of ship graffiti can be situated in a growing corpus of material informing us about the cognitive relationship the townspeople of Winchelsea, and the residents of its nearest neighbours had with the sea.

Due to the frequent storm and flooding events that the sea brought to Winchelsea (e.g. Eddison 1998: 65-87), Rye (Draper 2009: 5) and New Romney (Draper \& Meddens 2009: 18-20) - and the associated loss of life, land and material damage - while at the same time providing the principal means of income for the towns, it is to be expected that their relationship with the sea would have been an ambiguous one. For example, at New Romney, it has been suggested that the stone-built churches and hospitals would have been a natural refuge as they would have offered both physical and spiritual protection during storms (Draper \& Meddens 2009: 67). However, the weather was not the only reason to appeal to a higher power. At Rye, following the Black Death and French Raids, the Friary was relocated inside the town's walls in 1378 and works were conducted on the parish church in the fifteenth century. Gillian Draper $(2009$ : 98, 133) has suggested that these events might relate to the townspeople 
investing in spiritual protection. However, it should also be noted that the church served a dual function, also serving as the location for civic meetings (Jervis 2015: 11).

The question of who is responsible for the graffiti's creation remains a complicated one. The variability in the level of detail and quality in the collection of ship graffiti prohibits a straightforward explanation. While some graffiti (St Thomas 3, 5 and 6) might suggest some form of nautical knowhow, this knowledge might have been borne out of observation at the Winchelsea waterfront or elsewhere, rather than direct experience. This at least means that this particular collection of ship graffiti, was not necessarily made by people with some form of experience at sea. However, at the same time, it is impossible to claim that they were not made by people with some form of nautical experience. It is therefore argued here that the inscribing of ships in churches such as St Thomas could have been a practice that cuts across different communities of practice (Wenger 1998) and social groups. Such a hypothesis makes sense in a port town such as Winchelsea where not only sailors or the fishing community would have felt the need to protect themselves during their activities on ships, but also otherwise land-locked groups such as pilgrims on their way to St James of Compostela (Martin \& Martin 2004: 21; Draper 2009: 37) or military personnel mustering at Winchelsea and preparing for battle overseas (Sylvester 1999b: 137; Rose 2013: 133-4).

\section{Seascape in Blackfriars Barn undercroft}

Blackfriars Barn, situated on Rectory Lane, opposite the Weslyan Chapel, is the current name for the remains of an early $14^{\text {th }}$ century building (Figure 1 ). It takes its name from its use as a barn during the $19^{\text {th }}$ century, but does not appear to have been related to the Blackfriars. After a fire in the early $20^{\text {th }}$ century, the barn was demolished, revealing the ruins of a large building. Its size and the presence of a conspicuous undercroft underneath suggest that it was not a domestic building, but might have had a civic role. Martin and Martin (2004: 133) have dated the building to ca. 1300, however it was abandoned by the time of the 1366 rental, and was allegedly in ruins by 1499 (Martin \& Martin 2004: 69). The cellar comprises of three chambers: a 5-bay central barrel vault flanked by two quadripartite vaulted chambers. The western and eastern chambers have two windows which open onto light wells. The cellar is accessed by a wide staircase in the southern corner of the eastern chamber and would have provided direct access to the street. In the northern corner of the same chamber a hearth was built-in (Figure 10). There is no direct connection between the undercroft and the building on top and could thus have been used separately. Given the presence of windows and a hearth, it is unlikely the cellar was used for storage alone. Alternatively, it could have served as a tavern, but this must remain speculative. Since the cellar was separate from the building on top, it is unclear whether it continued to be used after the abandonment of the building above in 1366 . By the late $18^{\text {th }}$ or early $19^{\text {th }}$ century however, the undercroft was being used as a town dump (Champion 2012a).

Situated on the northern wall of the western bay (Figure 10), is a large seascape (Figure 11). Champion (2012a) considers the graffito to be the product of a single event, arguing that the ships were inscribed in wet plaster. The latter statement is supported by the observation of dragged and rolled edges along the inscribed lines, in contrast to well-defined edges more commonly associated with inscriptions in dry plaster. Such rolled edges were also picked up by the RTI survey (Figure 12). In total, twelve individual ships were identified and recorded (Also Champion, in his 2012a report, counted 12 ships). Tracings of the four RTIs made to record the wall and individual descriptions of every individual ship can be found in a grey literature report that can be requested from the National Trust (Dhoop 2015b).

\section{Interpretation}


The ships in the seascape in Blackfriars Barn undercroft are generally depicted with a straight stern, while both straight and curved stems occur. The strakes were carved in straight lines between the latter two elements. About half also have some sort of superstructure, mostly at the stern, but sometimes also above the bow. The majority show a single mast, some with a yard, furled sail, and stays and / or shrouds. Two ships, Blackfriars Barn 3 and 6 were most likely drawn with a sternpost rudder (Table 2). However, the straight stern discernible on most of the ships implies that they most likely represent vessels with sternpost rudders as well. All of these characteristics are again common for most medieval ship graffiti in England (Champion 2015b: 344).

In terms of what sort of ships are depicted, it is notable that also in this collection double-ended Nordic and 'hulc' tradition ships are absent. Champion's (2012a) suggestion that all are 'cogs' or 'early carracks' is perhaps a bit too specific. Since both ships with high-raking straight stems and curved stems were inscribed, it would appear that both cogs of the archaeological definition and medieval Nordic ships were depicted and, if the seascape was created post the 1440 's, possibly carvel-built ships as well. Although there certainly are differences in 'style' between the two collections (although this is hard to tell because of the difference in scale), the similarities are striking. All ships are shown in profile, most have superstructures, a single mast, yard, furled sails, and so forth. All of these are characteristics that the ship graffiti in both collections share with ship graffiti all over England (Champion 2015a: 86, 2015b).

\section{Dating}

As was the case with the graffiti in St Thomas' church, a stylistic dating based on the single masts and sternpost rudders is problematic. The earliest possible date that the graffiti could have been made can only be estimated by the date the cellar was taken into use. Martin and Martin (2004: 133) date the Blackfriars Barn building to ca. 1300, providing a very rough terminus post quem.

Also a latest possible date for the creation of the graffiti is again hard to establish. There are three dates that might offer a possible terminus ante quem. The first is the moment Martin and Martin (2004:69) argue Blackfriars Barn was ruined in 1499. However, the undercroft was separate from the building on top and could have stayed in use. The second is the moment when New Winchelsea fell out of use as a harbour: ca. 1530 (Martin \& Martin 2004: 198). However, as was the case with the graffiti in the church, also this date should be considered tentative. The third and most definite terminus ante quem comes from the moment the undercroft became used as a town dump in the late $18^{\text {th }}$ century.

\section{Context and meaning}

The context of the graffiti in Blackfriars Barn undercroft differs from the one in St Thomas' church in three ways: it concerns an entire seascape that was sculpted in a single event instead of individual ships over time, it was engraved in wet plaster instead of stone, and it is situated in an ostensibly secular building instead of an ecclesial one. Although the ships in the two collections share a lot of characteristics, there are also certain details that differ. While three of the ships in St Thomas' church were depicted at anchor, this is (most likely) not the case with the vessels in the undercroft. The occurrence of topcastles and flags is also unique to the ships in the undercroft (but is commonplace amongst other examples of recorded ship graffiti, Champion 2015b: 344).

Champion and Cohen (2013) have floated the hypothesis that the seascape in Blackfriars Barn undercroft could represent the famous 'Battle of Winchelsea' and might have had a commemorative function. In 1350, the English fleet, under command of Edward III with the Black Prince (1330-1376), mustered at - and set out from - Winchelsea to the straits of Dover to confront a Castilian Fleet. The 
English were victorious in the battle that ensued but an unconfirmed number of vessels were sunk on both sides (Rose 2013: 133-4).

This idea might not be as far-fetched as it sounds. The date of the battle (1350) fits within the suggested date-range of the graffiti (c. $1300-1499,1530$ or late $18^{\text {th }}$ century) and sailors from Winchelsea would certainly have participated in the Battle. The town would also have functioned as the main logistical hub (perhaps together with Rye) to supply the fleet with victuals. Winchelsea would thus certainly have had a vested interest in the battle and after their victory, some sailors must have returned. The additional details, such as flags and topcastles, also tend to be more prevalent in depictions of ships on media - such as town seals (Ewe 1972) - which represent vessels fitted for warfare or ones which intend to display a form of civic pride. However, there are also arguments against the idea that a sea battle is depicted. First, one would assume that both fleets would be shown and that whoever made the engraving would have wanted to distinguish between the two sides. Although the rival fleet could have been depicted on another wall of which the plaster is now lost (Champion in his 2012a report noted surviving plaster elsewhere in the undercroft containing evidence of graffiti), there is nothing in the surviving seascape that would suggest this. Second, most vessels appear to be going in the same direction, whereas in a battle one would expect to see groups of ships going in opposition to each other (for example the manuscript illuminations in Flatman 2009: 79, figure 70, 93, figure 87, 103, figure 99, 105, figure 103). Third, while in battle, the ships would presumably have their sails up in order to try to get alongside each other to board the enemy vessel. Also for this, there is no indication in the graffiti.

The impression one gets of the graffiti is of a sea of masts and rigging. Therefore, it might simply represent the everyday maritime activity at a roadstead in the harbour. On the other hand, if the seascape does indeed commemorate an event, it is perhaps more likely that what is shown is - instead of a battle - a grand fleet assembled prior to setting out for war. These occasions would have been highly relevant and memorable for a naval mustering point like Winchelsea and definitely worth inscribing in plaster and commemorating.

If the seascape was indeed made to commemorate any of these events, the graffiti should most likely not be seen as a formal or official tribute. The crude nature of the drawings suggests a more informal remembrance. Kate Giles (2007: 107) has stated that seeing an image in medieval times was understood as an essential part of understanding and remembering. Perhaps the seascape was made by people who lived through the battle, had worked in town or at the waterfront to supply the ships during one of the many occasions the English fleet mustered in the Camber, or had simply heard stories that they wanted to visually express. In doing this, they present another facet to their relationship with the sea, one in which they acknowledged and perhaps commemorated a beneficial aspect of their location near it. If this is the case, it could be an indication that, as Champion (2015b: 349) has suggested, some of the other pre-Reformation ship graffiti may have served a similar commemorative purpose.

\section{Conclusions}

In St Thomas' church, eleven possible ship graffiti were identified and recorded. Most likely, a variety of ship types are represented, including medieval Nordic ships, cogs of the archaeological definition and perhaps carvel ships. If made in the context of Winchelsea's function as a harbour, the inscriptions making up the collection should probably be dated between sometime after 1291 and ca. 1530. The individual engravings show characteristics that are common to most medieval ship graffiti in England and vary in quality. It is argued that the inscribing of ships in St Thomas could have been a means of 
spiritual protection and a devotional practice - the giving of a votive offering in an act of prayer - that, at least in Winchelsea, cut across different communities of practice and social groups.

In the Blackfriars Barn undercroft, twelve ships were identified and recorded that together constitute one large seascape. The dating is problematic and could be situated between a range as wide as ca. 1300 and the late $18^{\text {th }}$ century. However, if it is accepted that the graffiti was made at a time when Winchelsea could function as a harbour, a date between ca. 1300 and 1530 can be suggested. Also the engravings in the cellar show characteristics that are common to most medieval ship graffiti in England and depict the same variety of ships found in St Thomas' church. The seascape can possibly be interpreted as an occasion of informal remembrance, perhaps of the general maritime activities at a roadstead in the harbour, or the 1350 'Battle of Winchelsea', or more likely, the gathering of a large fleet before setting out for war.

The variety in the level of detail and quality of the recorded ships has accentuated some of the complexities involved in interpreting, dating and finding meaning in ship graffiti. Yet, despite - or perhaps because of - this ambiguity, ship graffiti can become a valuable resource to contemplate the multifaceted relationships people in coastal communities had with their maritime environment.

\section{Acknowledgements}

The Survey came to fruition thanks to the support of the church authority, the Winchelsea Archaeological Society, in particular Richard Comotto, and the National Trust, in particular Nathalie Cohen and Andrew Dyer. Also several of our colleagues at the University of Southampton should be acknowledged for their help, specifically Julian Whitewright, Fraser Sturt, Jon Adams, Juan Pablo Olaberria, David Selmo and Sarah Stark. A special word of thanks is in place for Matthew Champion for his many insightful comments on an earlier draft of this article. Lastly, the authors much appreciated the comments of the peer reviewers and editor which improved the quality of the paper.

\section{References}

Adams, J., 2013, A Maritime Archaeology of Ships. Innovation and Social Change in Medieval and Early Modern Europe. Oxford.

Blair, C., Goodall, J. and Lankester, P., 2000, The Winchelsea Tombs Reconsidered, Church Monuments 15, 5-30.

Bonino, M., 1975, A Medieval Graffito at Finale Ligure (Savona, Italy), The Mariner's Mirror, 61, 291-2.

Champion, M., 2011, Reading the writing on the wall: the Norfolk Medieval Graffiti Survey, Current Archaeology, 256, 36-41.

Champion, M., 2012a, Blackfriars Barn Undercroft, Winchelsea, East Sussex. Graffiti Survey Record. Unpublished report for the National Trust.

Champion, M., 2012b, The Medium is the Message: Votive Devotional Imagery and Gift Giving amongst the Communality in the Late Medieval Parish, Peregrinations: Journal of Medieval Art and Architecture, III, 103-123.

Champion, M., 2015a, Medieval Graffiti, The Lost Voices of England's Churches. London.

Champion, M. 2015b, Medieval Ship Graffiti in English Churches: Interpretation and function, The Mariner's Mirror, 101, 343-350. 
Champion, M. and Cohen, N., 2013, Victory Graffiti in the Undercroft?, National Trust, arts, buildings, collections bulletin, winter issue February 2013, pp. 8.

Cooper, W. D., 1850, The History of Winchelsea, one of the Ancient Towns added to the Cinque Ports. Lewes.

Crumlin-Pedersen, O., 2000, To be or not to be cog: the Bremen Cog in perspective, The International Journal of Nautical Archaeology 29, 230-246.

Dhoop, T., 2015a, Winchelsea Harbour Geotechnical Survey 2015. Geotechnical investigations at the ancient port site. Unpublished report for the National Trust.

Dhoop, T., 2015b, Winchelsea Harbour Geotechnical Survey 2015. Ship graffiti survey at St Thomas church and Blackfriars Barn undercroft. Unpublished report for the National Trust.

Dhoop, T., forthcoming, Classifying and Naming Archaeological Assemblages: Some Lessons from Shipwreck Archaeology, Terra Incognita 8.

Draper, G., 2009, A History of a Sussex Cinque Port to 1660. Chichester.

Draper, G., and Meddens, P., 2009, The Sea and the Marsh, The Medieval Cinque Port of New Romney revealed through archaeological excavations and historical research. London.

Earl, G., Martinez, K. and Malzbender, T., 2010, Archaeological applications of polynomial texture mapping: analysis, conservation and representation, Journal of Archaeological Science 37, 2040-2050.

Eddison, J. 1998, Catastrophic Changes: A Multidisciplinary Study of the Evolution of the Barrier Beaches of Rye Bay, in J. Eddison, M. Gardiner \& A. Long (eds.), Romney Marsh, Environmental Change and Human Occupation in a Coastal Lowland, 65-87, Oxford.

Emden, A. B., 1922, Graffiti of Medieval Ships, From the Church of St. Margaret's-at-Cliffe, Kent, The Mariner's Mirror 8, 167-173.

Ewe, H., 1972, Schiffe auf Siegeln. Rostock.

Færøyvik, Ø., 1987, Vestlandsbåtar: Frå oselvar til sunnmørsåttring. Oslo.

Flatman, J., 2002, Illuminating Ships: Interrogating the Evidence from Images and Materials. PhD thesis University of Southampton.

Flatman, J., 2009, Ships and Shipping in Medieval Manuscripts. London.

Fleming, J., 2001, Graffiti and the Writing Arts of Early Modern England, Philadelphia.

Freeth, T., Bitsakis, Y., Moussas, X., Seiradakis, J., Tselikas, A., Mangou, H., Zafeiropoulou, M., Hadland, R., Bate, D. and Ramsey, A., 2006, Decoding the ancient Greek astronomical calculator known as the Antikythera Mechanism, Nature, 444, 587-591.

Friel, I., 1994, The Carrack: The Advent of the Full Rigged Ship, in R. Unger (ed.), Cogs, Caravels and Galleons, 77-90. London.

Friel, I. 1995, The Good Ship, Ships, Shipbuilding and Technology in England 1200-1520, London.

Friel, I., 2004, The Ship Graffiti, in R. Bell and K. Rodwell (eds.), Acton Court: the Evolution of a Tudor Courtiers House, 275-278, English Heritage. 
Friel, I., 2011, 'Ignorant of Nautical Matters'? The Mariner's Mirror and the iconography of medieval and sixteenth-century ships, The Mariner's Mirror 97, 77-96.

Gardiner, M., 2007, Graffiti and Their Use in Late Medieval England, Ruralia 6, 265-276.

Giles, K., 2007, Seeing and Believing: Visuality and Space in Pre-Modern England, World Archaeology 39.1, 105-121.

Greenhill, B., 2000, The Mysterious Hulc, The Mariner's Mirror 86, 3-18.

Gabov, A. and Bevan, G., 2011, Recording the Weathering of Outdoor Stone Monuments Using Reflectance Transformation Imaging (RTI): The Case of the Guild of All Arts (Scarborough, Ontario), Journal of the Canadian Association for Conservation, 36, 3-14.

Hammer, $\varnothing$., Bengtson, S., Malzbender, T. and Gelb, D., 2002, Imaging fossils using reflectance transformation and interactive manipulation of virtual light sources, Palaeontologia Electronica, 5.4, $1-9$.

Hutchinson, G., 1994, Medieval Ships and Shipping. London and Washington.

Jervis, B., 2015, Assessing Urban Fortunes in Six Late Medieval Ports: an Archaeological Application of Assemblage Theory, Urban History, Available on CJO2015 doi:10.1017/S0963926815000930.

Klausmeyer, P., 2013, Applications of Reflectance Transformation Imaging (RTI) in a Fine Arts Museum: Examination, Documentation, and Beyond. Lecture presented at the 3D Digital Documentation Summit held July 10-12, 2012 at the Presidio, San Francisco, CA. Natchitoches, Louisiana: National Center for the Preservation Technology and Training at Northwestern State University of Louisiana.

https://ncptt.nps.gov/blog/applications-of-reflectance-transformation-imaging-rti-in-a-fine-artsmuseum-examination-documentation-and-beyond/ (consulted 17/11/2015).

le Bon, L., 2001, The "Bryggen Shipstick": A Challenge in Art and Ship Technology, in I. Øye, A. Christensson and E. Mundahl (eds.), Ships and Commodities, The Bryggen Papers Supplementary Series 7, 9-34, Bergen.

Liebgott, N-K., 1973, A wooden Norwegian calendar of 1457 with ship graffiti, Problems relating to the source value of primitive representations of ships, The International Journal of Nautical Archaeology 2, 147-158.

Lilley, K., Lloyd, C. and Trick, S., 2005, Mapping the Medieval Townscape: a digital atlas of the new towns of Edward $l$, Published online on the Archaeology Data Service: http://archaeologydataservice.ac.uk/archives/view/atlas ahrb 2005/index.cfm

Manfredi, M., Williamson, G., Kronkright, D., Doehne, E., Bearman, G., Jacobs, M. and Marengo, E., 2013, Measuring Changes in Cultural Heritage Objects with Reflectance Transform Imaging, in Proceedings of the Digital Heritage International Congress, Volume 2, Marseille.

Malzbender, T., Gelb, D. and Wolders, H., 2001, Polynomial texture maps. Paper presented at SIGGRAPH '01: Proceedings of the 28th Annual Conference on Computer Graphics and Interactive Techniques, Los Angeles, USA, 12-17 August 2001, http://dl.acm.org/citation.cfm?id=383320

Martin, D. and Martin, B., 2004, New Winchelsea Sussex. A Medieval Port Town, London \& Swindon.

McGrail, S., 2001, Boats of the World. Oxford. 
McGrail, S., 2014, Early Ships and Seafaring, Water Transport within Europe. Barnsley.

Miles, J., Pitts, M., Pagi, H. and Earl, G., 2014, New applications of photogrammetry and reflectance transformation imaging to an Easter Island statue, Antiquity, 88, 596-605.

Miles, J., Pitts, M., Pagi, H. and Earl, G., 2015, Photogrammetry and RTI Survey of Hoa Hakananai'a Easter Island Statue, in Traviglia, A. (ed.), Across Space and Time. Papers from the $41^{\text {st }}$ Conference on Computer Applications and Quantitative Methods in Archaeology, Perth, 25-28 March 2013, 144-55, Amsterdam.

Miller, R., 2003, The Early Medieval Seaman and the Church: Contacts Ashore, The Mariner's Mirror 89, 132-150.

Mott, L. V., 1990, Medieval Ship Graffito in the Palau Reial Major at Barcelona, The Mariner's Mirror, 76, 13-21.

Mudge, M., Voutaz, J., Schroer, C. and Lum, M., 2005, Reflection Transformation Imaging and Virtual Representations of Coins from the Hospice of the Grand St. Bernard, in M. Mudge, N. Ryan and R. Scopigno (eds.), The 6th International Symposium on Virtual Reality, Archaeology and Cultural Heritage (VAST 2005), Pisa.

Mudge, M., Malzbender, T., Schroer, C. and Lum, M., 2006, New Reflection Transformation Imaging Methods for Rock Art and Multiple-Viewpoint Display, in M. loannides, D. Arnold, F. Niccolucci, K. Mania (eds.), The $7^{\text {th }}$ International Symposium on virtual Reality, Archaeology and Cultural Heritage (VAST 2006), Nicosia.

Mudge, M., Malzbender, T., Chalmers, A., Scopigno, R., Davis, J., Wang, O., Gunawardane, P., Ashley, M., Doerr, M., Proenca, A. and Barbosa, J., 2008, Image-Based Empirical Information Acquisition, Scientific Reliability, and Long-Term Digital Preservation for the Natural Sciences and Cultural Heritage, Europgraphics 2008: Tutorial Notes, http://homepages.inf.ed.ac.uk/rbf/CVonline/LOCAL COPIES/MUDGE/EG-mudge-tutorial-notesfinal.pdf

Peake, J., 2012, Graffiti and Devotion in Three Maritime Churches, in T. A. Heslop, E. Mellings and M. Thofner (eds.), Art, Faith and Place in East Anglia: from Prehistory to the Present, 148-162, Suffolk.

Perry, M., 2010, Tudor House Museum. Southampton: the incised and painted decoration in rooms F01-03. Unpublished conservation report. Perry Lithgow Partnership.

Pritchard, V., 1967, English Medieval Graffiti. Cambridge.

Pritchard, V., 1987, Some English Medieval Ship Graffiti, The Mariner's Mirror 73, 318-320.

Rose, S., 2013, England's Medieval Navy, 1066-1509. Barnsley.

Sylvester, D., 1999a, Shaping the Urban Landscape of Maritime England: the Role of the King and Barons in the 1292 Founding of New Winchelsea, in J. Bill and B. L. Clausen (eds.), Maritime Topography and the Medieval Town; Proceedings of the Third International Waterfront Conference, 153-160. Copenhagen.

Sylvester, D., 1999b, Maritime Communities in Pre-Plague England: Winchelsea and the Cinque Ports. PhD Thesis Fordham University.

Tinniswood, J. T., 1949, English Galleys, 1272-1377, The Mariner's Mirror 35, 276-315. 
Wenger, E., 1998, Communities of Practice, Learning, Meaning and Identity, Cambridge.

Westerdahl, C., 2013, Medieval Carved Ship Images Found in Nordic Churches: the poor man's votive ships?, The International Journal of Nautical Archaeology 42, 337-347.

\section{Captions}

\section{Figures}

Figure 1: Winchelsea as laid out in the late $13^{\text {th }}$ century. The map is based on the 1292 rental and earthwork-features taken from Lilley et al. 2005. (CThomas Dhoop

Figure 2: Detail of St Thomas 1. From left to right: engravings visualised with flat light, raking light, specular enhancement and surface normals. (CThomas Dhoop

Figure 3: RTI-setup (left) and overview of the lighting angels (right). The target is in the middle and the white squares represent each light source for which there is an individual picture. For this particular RTI, fifty pictures were taken, making fifty light sources in total. (c) Catriona Cooper

Figure 4: Spatial configuration of St Thomas' church with the location of the graffiti indicated in red. Drawing by Thomas Dhoop, based on Martin and Martin 2004: 75, Figure 7.3.

Figure 5: Interpretation drawing of St Thomas 1. CThomas Dhoop

Figure 6: Interpretation drawing of St Thomas 5. (OThomas Dhoop

Figure 7: Interpretation drawing of St Thomas 3. CThomas Dhoop

Figure 8: Interpretation drawing of St Thomas 6. (CThomas Dhoop

Figure 9: From left to right: Interpretation drawings of St Thomas 2, 4, 7, 8, 9, 10 and 11. CThomas Dhoop

Figure 10: Spatial configuration of the Blackfriars Barn undercroft with the location of the seascape indicated in red. Drawing by Thomas Dhoop, based on Martin and Martin 2004: 122, Figure 9.39.

Figure 11: Interpretation drawing of the four RTI's taken from the northern wall of the western bay in the Blackfriars Barn undercroft (top) and the individual ships filtered out (bottom). CThomas Dhoop

Figure 12: Detail of the plaster surface in Blackfriars Barn undercroft visualised under specular enhancement. The inscribed lines are clearly associated with rolled edges, suggesting they were made in a wet plaster surface. CThomas Dhoop

\section{Tables}

Table 1: Features of the ship graffiti in St Thomas' church.

Table2: Features of the ship graffiti in Blackfriars Barn undercroft. 